\title{
PITUITARY LH CONTENT AND REPRODUCTIVE TRACT CHANGES DURING THE MOUSE OESTROUS CYCLE
}

\author{
AUDREY S. BINGEL* AND NEENA B. SCHWARTZ \\ Department of Physiology, University of Illinois College of Medicine, \\ Chicago, Illinois, U.S.A.
}

(Received 1st April 1968, revised 16th September 1968)

\begin{abstract}
Summary. Body, uterine, ovarian and pituitary weights, and pituitary LH content were determined on each day of the oestrous cycle of individually housed, spontaneously cyclic mice. Uterine and pituitary weights varied significantly; uterine weight was maximum at pro-oestrus and pituitary weight was maximum at oestrus. The cyclic changes in the vaginal smear cells were correlated with the cyclic ovarian changes; the morning of di-oestrus I ( 2 mornings after newly ovulated ova are found in the oviduct) was the most useful marker for cycle stage, since it could always be recognized as the 1st morning on which only leucocytes and nucleated epithelial cells (no cornified cells) were present in the vaginal smear. In additional studies, females, which had been previously grouped (ten/cage), were paired individually with males and killed on days of 'induced' pro-oestrus (pre-ovulatory) or oestrus (postovulatory). The organ weights and pituitary LH content of these mice did not differ significantly from those obtained for spontaneously cyclic mice on the corresponding 2 days of the cycle.
\end{abstract}

\section{INTRODUCTION}

Detailed descriptions of the anatomical changes occurring during the oestrous cycle in the reproductive tract of the mouse (Allen, 1922) and rat (Long \& Evans, 1922) were published more than 40 years ago. Since then the exact correlation between the appearance of the vaginal smear and the day on which newly ovulated ova can be found in the oviduct has been determined in the rat (Everett, 1964; Schwartz, 1964). Significant changes in pituitary LH content (Schwartz, 1964) and uterine weight and water content (Astwood, 1939; Schwartz, 1964) occur during the rat oestrous cycle. The fact that little work of this sort in the mouse has followed Allen's (1922) early study is presumably the result of the greater difficulty in correlating the vaginal smear picture with the concurrent ovarian stage of the cycle in this species. Allen occasionally found mice exhibiting anovulatory cycles, a phenomenon that has not been

* Present address : Department of Pharmacognosy and Pharmacology, University of Illinois College of Pharmacy, Chicago, Illinois, U.S.A. 
reported in the untreated rat. Recently, Wallace (1965a, b) has shown that ovulation occurs in mice within about $24 \mathrm{hr}$ after the appearance of swollen mucified epithelial cells (identified by fluorescent staining with acridine orange) in the vaginal smear.

The two-fold purpose of the present study in the mouse was to correlate the cyclic changes in the vaginal smear with those occurring simultaneously in the ovary, and to determine normal values for body, uterine, ovarian and pituitary weights, and pituitary LH content during the oestrous cycle. This was a prerequisite before the timing of $\mathrm{LH}$ release and ovulation could be investigated.

\section{MATERIALS AND METHODS}

Virgin female, albino mice were obtained from Charles River Mouse Farms, at 6 weeks of age; the majority were used experimentally when they were between 11 and 16 weeks of age. They were housed, one per cage, in environmentally controlled quarters (lights on from 05.00 to 19.00 hours). Vaginal smears were taken by saline lavage twice daily, at 09.00 and 16.00 hours, beginning 2 weeks after the animals arrived in the laboratory. The cell types were identified in unstained wet preparations.

Using the description of vaginal changes occurring during the oestrous cycle as a guide (Allen, 1922), attempts were made to select mice on the day of oestrus, i.e. on the morning after ovulation had occurred. At laparatomy under ether anaesthesia, the oviducts were examined using a dissecting microscope. If the oviducts were swollen and transparent, containing newly-ovulated ova (Burdick, Whitney \& Emerson, 1942), the animals were either killed (Day $0=$ oestrus), or the incision was sutured and the animal killed on one of the subsequent 4 days, designated 'ova +1 to 4 ' (see Plates 1 and 2, Figs. 1 to 5). The 5th day was again oestrus. These procedures eventually permitted an accurate prediction of the ovarian stage of the cycle by examination of the vaginal smear.

Mice were killed by cervical dislocation after weighing, and autopsies were performed at 10.00 hours. Pituitaries were quickly removed, weighed and frozen for subsequent LH assay by a modification (Schwartz, 1964; Schwartz \& Bartosik, 1962) of the ovarian ascorbic acid depletion method (Parlow, 1964). Oviducts were flattened under a coverslip and examined for ova under the microscope. Ovarian weights, and uterine wet and dry weights were determined. Ovaries and oviducts representative of each day of the cycle were preserved for histological study.

Approximately half the animals observed were exhibiting acyclical vaginal smear patterns. Attempts were made to 'induce' pro-oestrus and oestrus in such mice (Whitten, 1966). They were placed in groups of ten at 16.00 hours and paired individually with males at 09.00 hours 12 days later. If a pro-oestrous vaginal smear was obtained on the 3rd morning after pairing, the male was removed and the female was subjected to laparotomy at 10.00 hours. If the uterus contained intraluminal fluid and the oviducts were opaque and not distended, the mouse was either killed immediately as a pro-oestrous animal or 
on the next morning as an oestrous animal if newly ovulated ova were present in the oviducts. Body and organ weights were recorded as described above for spontaneously cyclic mice, and pituitaries were collected for LH assay.

\section{RESULTS}

\section{Body and organ weights and ovarian histology}

Table 1 shows that in the spontaneously cyclic group there were no significant differences in body or ovarian weights during the cycle. Highly significant differences occurred in uterine wet and dry weights and tissue-water content

TABLE ]

BODY AND ORGAN WEIGHTS OF CYGLIG MIGE (MEANS \pm S.D.)

\begin{tabular}{|c|c|c|c|c|c|c|}
\hline \multirow{2}{*}{$\begin{array}{l}\text { Day of } \\
\text { autopsy }\end{array}$} & \multirow{2}{*}{$\begin{array}{c}\text { Body } w t \\
(\mathrm{~g})\end{array}$} & \multicolumn{3}{|c|}{ Uterus } & \multirow{2}{*}{$\begin{array}{c}\text { Ovaries } \\
(\mathrm{mg})\end{array}$} & \multirow{2}{*}{$\begin{array}{l}\text { Pituitary } \\
\quad(m g)\end{array}$} \\
\hline & & $\begin{array}{c}W e t \\
(m g)\end{array}$ & $\begin{array}{l}D r y \\
(m g)\end{array}$ & $\begin{array}{c}\% \\
\text { Water }\end{array}$ & & \\
\hline $\begin{array}{c}\text { Day 0 } \\
\text { (Oestrus) }\end{array}$ & $\begin{array}{r}29 \cdot 0 \\
\pm 2 \cdot 2 \\
(13)\end{array}$ & $\begin{array}{c}171.90 \\
\pm 23.41 \\
(13)\end{array}$ & $\begin{array}{c}31 \cdot 79 \\
\pm 4 \cdot 82 \\
(13)\end{array}$ & $\begin{array}{r}81.47 \\
+1.59 \\
(13)\end{array}$ & $\begin{array}{c}13.65 \\
\pm 2.13 \\
(11)\end{array}$ & $\begin{array}{r}2.45 \\
+0.36 \\
(12)\end{array}$ \\
\hline $\begin{array}{c}\text { Ova }+1 \\
\text { (Metoestrus }\end{array}$ & $\begin{array}{l}27 \cdot 9 \\
\pm 1 \cdot 8 \\
(13)\end{array}$ & $\begin{array}{c}104.89 \\
\pm 13 \cdot 21 \\
(13)\end{array}$ & $\begin{array}{c}20 \cdot 39 \\
\pm 3 \cdot 09 \\
(13)\end{array}$ & $\begin{array}{c}80.57 \\
\pm 1.50 \\
(13)\end{array}$ & $\begin{array}{c}12.89 \\
\pm 2.59 \\
(11)\end{array}$ & $\begin{array}{l}1.92 \\
\pm 0.30 \\
(12)\end{array}$ \\
\hline $\begin{array}{c}\text { Ova +2 } \\
\text { (Di-oestrus I) }\end{array}$ & $\begin{array}{l}29 \cdot 5 \\
\pm 2 \cdot 4 \\
(19)\end{array}$ & $\begin{array}{r}94.36 \\
\pm 15 \cdot 51 \\
(19)\end{array}$ & $\begin{array}{c}18 \cdot 17 \\
\pm 3.31 \\
(19)\end{array}$ & $\begin{array}{c}80.78 \\
\pm 0.94 \\
(19)\end{array}$ & $\begin{array}{c}13.77 \\
\pm 3.18 \\
(16)\end{array}$ & $\begin{array}{r}1.90 \\
\pm 0.52 \\
(18)\end{array}$ \\
\hline $\begin{array}{c}\text { Ova }+3 \\
\text { (Di-oestrus II) }\end{array}$ & $\begin{array}{l}28 \cdot 5 \\
\pm 2.9 \\
(12)\end{array}$ & $\begin{array}{c}116.71 \\
\pm 19.91 \\
(12)\end{array}$ & $\begin{array}{c}20.78 \\
\pm 3.25 \\
(12)\end{array}$ & $\begin{array}{c}82 \cdot 11 \\
\pm 1 \cdot 62 \\
(12)\end{array}$ & $\begin{array}{l}12.33 \\
\pm 1.85 \\
(10)\end{array}$ & $\begin{aligned} & 1.92 \\
& \pm 0.30 \\
&(12)\end{aligned}$ \\
\hline $\begin{array}{c}\text { Ova }+4 \\
\text { (Pro-oestrus) }\end{array}$ & $\begin{array}{l}29 \cdot 0 \\
\pm 2 \cdot 4 \\
(12)\end{array}$ & $\begin{array}{c}206 \cdot 32 \\
\pm 42 \cdot 43 \\
(12)\end{array}$ & $\begin{array}{c}34 \cdot 00 \\
\pm 6 \cdot 04 \\
(12)\end{array}$ & $\begin{array}{c}83.36 \\
\pm 1.42 \\
(12)\end{array}$ & $\begin{array}{r}12.48 \\
+3.08 \\
(10)\end{array}$ & $\begin{array}{r}2.05 \\
\pm 0.65 \\
(12)\end{array}$ \\
\hline$\underset{P}{\mathrm{~F} \text { value* }}$ & $\begin{array}{l}0.93 \\
\text { N.S. }\end{array}$ & $\begin{array}{r}54 \cdot 19 \\
<0.01\end{array}$ & $\begin{array}{r}42 \cdot 15 \\
<0 \cdot 01\end{array}$ & $\begin{array}{r}8.63 \\
<0.01\end{array}$ & $\begin{array}{l}0.73 \\
\text { N.S. }\end{array}$ & $\begin{array}{c}3.29 \\
0.01<P<0.05\end{array}$ \\
\hline
\end{tabular}

* Analysis of variance for each variable (Snedecor, 1956). The $F$ value indicates the significance of differences among the five cycle stages (N.S. = not significant).

throughout the cycle, maximum values being found at pro-oestrus, when uterine distension was also observed. There was a significant variation in pituitary weight with cycle stage. Maximum pituitary weights were found on the morning of oestrus.

Sections of the gonads from five of these animals, representing each stage of the ovarian cycle are shown in Plates 1 and 2, Figs. 1 to 5. Ova can be found in the oviducts from the morning of Day 0 (oestrus) until the morning of ova +2 (di-oestrus I) (Plates 1 and 2, Figs. 1B, 2B, 3). On the morning of oestrus the ova are surrounded by cumulus cells, but the latter have completely disappeared by the morning of di-oestrus I. Newly formed corpora lutea (Pl. 1, Fig. 1A) are basophilic. By the morning of ova +1 (metoestrus) (Pl. 1, Fig. 2A) they begin to lose their basophilia; as they age they become increasingly eosinophilic 
(PI. 2, Figs. 3 to 5). The follicles destined to ovulate at the next oestrus are evident on the morning of ova +3 (di-oestrus II) (PI. 2, Fig. 4); they are still larger on the morning of ova +4 (pro-oestrus) (Pl. 2, Fig. 5).

The body and organ weights of the previously grouped mice killed on the day of induced pro-oestrus or oestrus are seen in Table 2. The body, ovarian, pituitary and uterine dry weights on these 2 days were found not to differ significantly; the uterine wet weight and water content were, however, significantly higher on the day of pro-oestrus. Values for pro-oestrus and oestrus

TABLE 2

BODY AND ORGAN WEIGHTS OF PREVIOUSLY GROUPED (P.G.) MICE (MEANS \pm S.D.)

\begin{tabular}{|c|c|c|c|c|c|c|}
\hline \multirow{2}{*}{$\begin{array}{l}\text { Day of } \\
\text { autopsy }\end{array}$} & \multirow{2}{*}{$\begin{array}{l}\text { Body wt } \\
(g)\end{array}$} & \multicolumn{3}{|c|}{ Uterus } & \multirow{2}{*}{$\begin{array}{c}\text { Ovaries } \\
(m g)\end{array}$} & \multirow{2}{*}{$\begin{array}{l}\text { Pituitary } \\
(m g)\end{array}$} \\
\hline & & $\begin{array}{c}\text { Wet } \\
(m g)\end{array}$ & $\begin{array}{l}D r y \\
(m g)\end{array}$ & $\begin{array}{l}\% \\
\text { Water }\end{array}$ & & \\
\hline $\begin{array}{c}\text { (Pro-oestrus) } \\
\mathrm{n}=10\end{array}$ & $\begin{array}{r}28 \cdot 2 \\
\pm 2 \cdot 6\end{array}$ & $\begin{array}{r}199.82 \\
+23.48\end{array}$ & $\begin{array}{r}32 \cdot 12 \\
\pm 3 \cdot 73\end{array}$ & $\begin{array}{r}83.91 \\
\pm 0.87\end{array}$ & $\begin{array}{r}10 \cdot 68 \\
\pm 4 \cdot 18\end{array}$ & $\begin{array}{r}2.11 \\
\pm 0.42\end{array}$ \\
\hline $\begin{array}{c}\text { (Oestrus) } \\
\mathrm{n}=12\end{array}$ & $\begin{array}{r}28 \cdot 2 \\
\pm 2 \cdot 0\end{array}$ & $\begin{array}{r}164 \cdot 59 \\
\pm 19 \cdot 02\end{array}$ & $\begin{array}{r}31 \cdot 29 \\
\pm 3 \cdot 82\end{array}$ & $\begin{array}{r}80.99 \\
\pm 0.85\end{array}$ & $\begin{array}{r}12 \cdot 55 \\
\pm 2 \cdot 21\end{array}$ & $\begin{array}{r}2.31 \\
\pm 0.37\end{array}$ \\
\hline$\underset{P}{\mathrm{t} \text { value* }}$ & $\begin{array}{l}0.00 \\
\text { N.S. }\end{array}$ & $\begin{aligned} & 3.89 \\
< & 0.001\end{aligned}$ & $\begin{array}{l}0.51 \\
\text { N.S. }\end{array}$ & $\begin{aligned} & 7.94 \\
< & 0.001\end{aligned}$ & $\begin{array}{l}1.35 \\
\text { N.S. }\end{array}$ & $\begin{array}{l}1 \cdot 18 \\
\text { N.S. }\end{array}$ \\
\hline $\begin{array}{c}\text { (Pro-oestrus) } \\
\text { Cyc. versus P.G. } \\
\text { t value† } \\
P \\
\text { (Oestrus) }\end{array}$ & $\begin{array}{l}0.76 \\
\text { N.S. }\end{array}$ & $\begin{array}{l}0.43 \\
\text { N.S. }\end{array}$ & $\begin{array}{l}0.85 \\
\text { N.S. }\end{array}$ & $\begin{array}{l}1.06 \\
\text { N.S. }\end{array}$ & $\begin{array}{l}1 \cdot 10 \\
\text { N.S. }\end{array}$ & $\begin{array}{l}0.25 \\
\text { N.S. }\end{array}$ \\
\hline $\begin{array}{c}\text { Cyc. versus P.G. } \\
\text { t value† } \\
P\end{array}$ & $\begin{array}{l}0.94 \\
\text { N.S. }\end{array}$ & $\begin{array}{l}0.85 \\
\text { N.S. }\end{array}$ & $\begin{array}{l}0.29 \\
\text { N.S. }\end{array}$ & $\begin{array}{l}0.92 \\
\text { N.S. }\end{array}$ & $\begin{array}{l}1 \cdot 21 \\
\text { N.S. }\end{array}$ & $\begin{array}{l}0.93 \\
\text { N.S. }\end{array}$ \\
\hline
\end{tabular}

* Group comparison (Snedecor, 1956) for each variable: pro-oestrus versus oestrus in P.G. mice.

$\dagger$ Group comparison for each variable at each stage: data from cyclic mice (Table 1) versus data from P.G. mice.

obtained from the mice with spontaneous cycles (Table 1) were compared with the corresponding values for the mice with induced cycles. No significant differences were found (Table 2).

\section{LH content of the pituitary}

The values obtained for pituitary LH content of spontaneously cyclic and of previously grouped mice that had been induced to cycle are in Table 3 . The

\section{EXPLANATION OF PLATE 1}

Mouse ovaries and oviducts, $\times 80$.

Figs. 1A and 1B. Day 0 (oestrus). The newly-formed deep blue (H \& E) cL is in a collapsed condition. Ova located in cumulus cells in thin-walled ampulla of oviduct.

Figs. 2A and 2B. Ova +1 (metoestrus). The cL on this day show slight eosinophilia; they appear purple rather than deep blue and have a lumen of moderate size. The ova have passed beyond the ampulla of the oviduct; some cumulus cells are present but they no longer surround the ova. 
PLATE 1

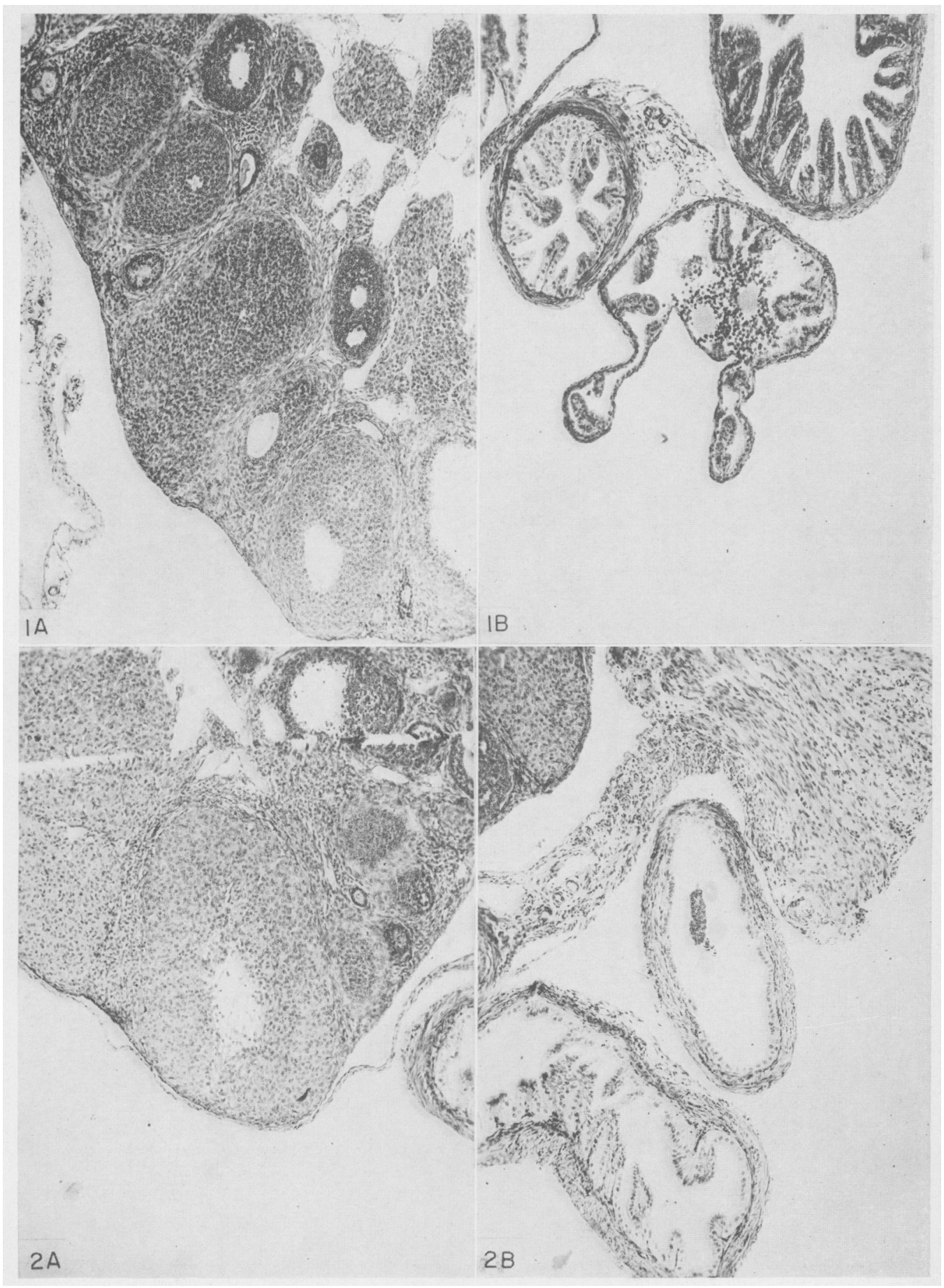

(Facing p. 218) 
PL.STE 2

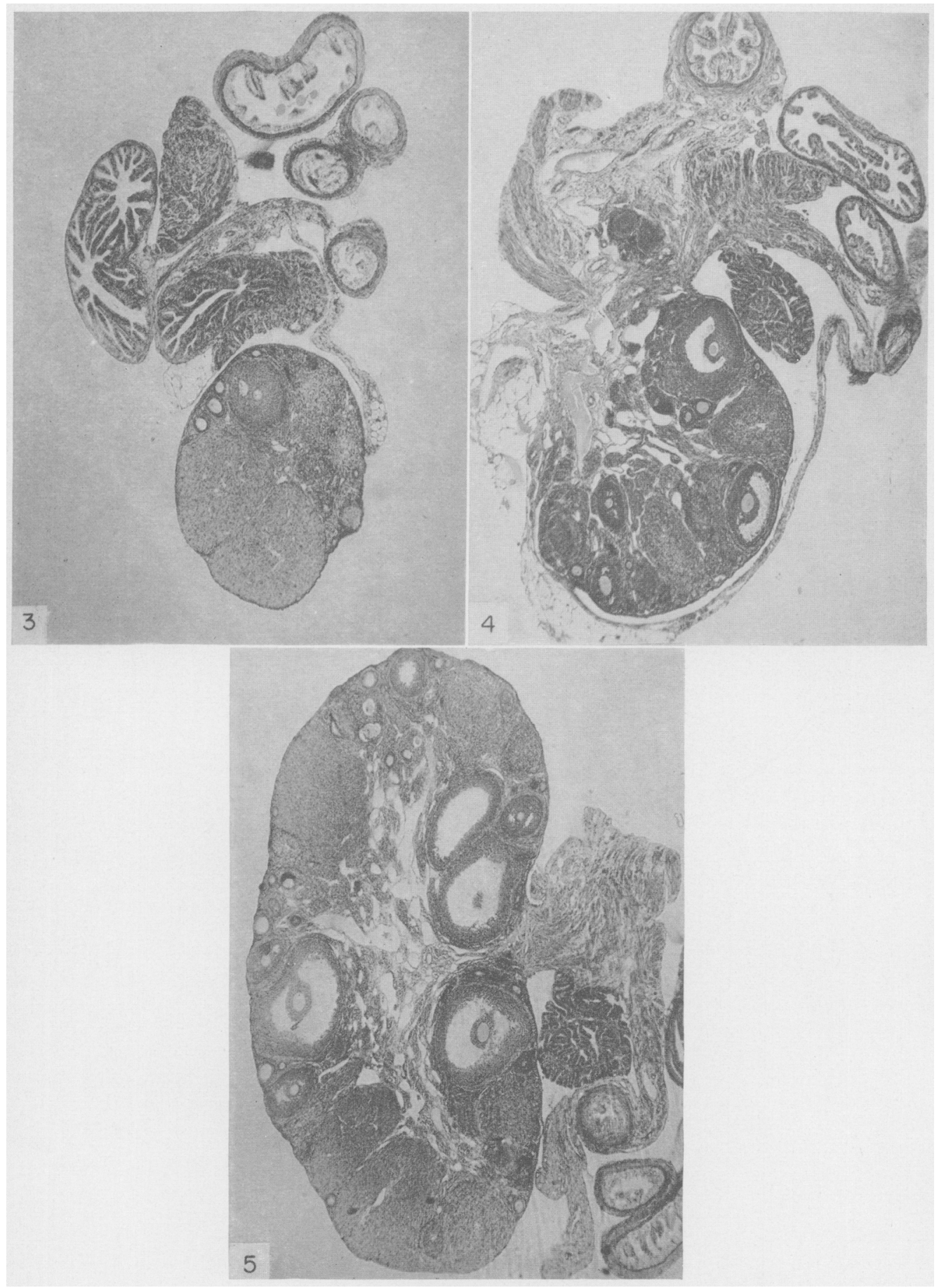


mean values appear to shift during the cycle; however, the confidence limits overlap and are quite wide. A chi square test for homogeneity of the values for the five pools of pituitaries, obtained from the spontaneously cyclic mice at each of the five stages of the oestrous cycle, respectively, showed no significant difference among the cycle stages.

LH content on the days of pro-oestrus or oestrus in the previously grouped mice was not significantly different from LH content in the pituitaries of cyclic

TABLE 3

PITUITARY LH GONTENT OF SPONTANEOUSLY CYCLIC AND PREVIOUSLY GROUPED (P.G.) MICE

\begin{tabular}{|c|c|c|c|c|}
\hline $\begin{array}{l}\text { Cycle* } \\
\text { stage }\end{array}$ & $\begin{aligned} L H, \mu g \\
(95 \% \mathrm{C} \\
\text { Cyclic }\end{aligned}$ & $\begin{array}{l}\text { ituitary } \\
\text { f. Lim.) } \\
P . G .\end{array}$ & $\begin{array}{l}\chi^{2} \\
\text { test for homogeneity }\end{array}$ & $\begin{array}{c}\text { LH, } \mu g \text { lpituitary }(95 \% \\
\text { Conf. Lim.) Weighted } \\
\text { mean potencies }\end{array}$ \\
\hline Pro-oestrus & $\begin{array}{c}0.62 \\
(0 \cdot 14-1 \cdot 37)\end{array}$ & $\begin{array}{c}0 \cdot 76 \\
(0 \cdot 22-1 \cdot 64)\end{array}$ & $\chi^{2}=0.077$ (N.S.) & $\begin{array}{c}0.69 \\
(0 \cdot 32-1 \cdot 49)\end{array}$ \\
\hline Oestrus & $\begin{array}{c}0.30 \\
(0.10-0.55)\end{array}$ & $\begin{array}{c}0 \cdot 30 \\
(0 \cdot 10-0 \cdot 56)\end{array}$ & $\chi^{2}=0.001$ (N.S.) & $\begin{array}{c}0.30 \\
(0 \cdot 16-0.55)\end{array}$ \\
\hline Metoestrus & $\begin{array}{c}0.59 \\
(0 \cdot 22-1 \cdot 12)\end{array}$ & & & \\
\hline Di-oestrus I & $\begin{array}{c}1.02 \\
(0.61-1.67)\end{array}$ & & & \\
\hline Di-oestrus II & $\begin{array}{c}0.54 \\
(0 \cdot 03-1 \cdot 65)\end{array}$ & & & \\
\hline $\begin{array}{l}\chi^{2} \text { test for } \\
\text { homog. } \\
\text { (Bliss, 1956) }\end{array}$ & $\begin{array}{c}\text { (Among } \\
\text { stages) } \\
\mathrm{df}=4 \\
\chi^{2}=7.21 \\
0 \cdot 10<P<0.25\end{array}$ & & & $\begin{array}{c}\text { (Between weighted } \\
\text { potencies) } \\
\mathrm{df}=1 \\
\chi^{2}=3.02 \\
0.05<P<0.10\end{array}$ \\
\hline
\end{tabular}

* Each of the two pro-oestrous pools contained ten pituitaries; the other five pools each contained twelve pituitaries.

+ Potencies of pro-oestrous and oestrous pituitaries, respectively, combined by weighting (Bliss, 1956).

mice. The values were combined for each day and the weighted mean prooestrous and oestrous potencies retested for homogeneity. The significance was borderline $(0.05<P<0 \cdot 10)$; the confidence limits for the pro-oestrous and oestrous values still overlapped, but the weighted mean for each of the two stages lay outside the confidence limits for the other.

\section{EXPLANATION OF PLATE 2}

Mouse ovaries and oviducts, $\times 32$.

Fig. 3. Ova +2 (di-oestrus I). The cL are pale purple, lumen no longer distinguishable. Ova, but no cumulus cells, still visible in the thick-walled portion of the oviduct.

FIg. 4. Ova +3 (di-oestrus II). The CL are now pink. Medium-large follicle visible which probably would have ovulated at next oestrus. Ova no longer present in oviducts.

FIG. 5. Ova +4 (pro-oestrus). The cL are still pink, and large follicles, probably destined to ovulate that night, can be seen. 
The vaginal cell cycle

Correlation of ovarian, uterine and vaginal characteristics at each stage of the oestrous cycle (Tables 1 and 2; Plates 1 and 2, Figs. 1 to 5) subsequently permitted prediction of cycle stage from vaginal smear alone. Typical vaginal smear cell types found on each day of the oestrous cycle are listed in Table 4. These might vary considerably from mouse to mouse and even within the same mouse. When the duration of the oestrous cycle became recognizable by vaginal smear examination alone, it was observed that, of the mice exhibiting regularly recurring oestrous cycles, the majority manifested 5-day cycles; only a small number exhibited 4-day cycles.

The most consistent vaginal smear, regardless of cycle length, is that found at di-oestrus I; the vagina at this stage contains virtually only leucocytes and nucleated epithelial cells. In addition to the latter cells, degenerating ova were

TABLE 4

VAGINAL SMEARS DURING THE MOUSE OESTROUS CYCLE $\dagger$

\begin{tabular}{c|c|cccccc}
\hline \multirow{3}{*}{$\begin{array}{c}\text { Cycle } \\
\text { length }\end{array}$} & Time & \multicolumn{5}{|c}{ Cycle stage } \\
\cline { 2 - 7 } & & Pro-oestrus & Oestrus & Metoestrus & Di-oestrus I & Di-oestrus II \\
\cline { 2 - 7 } 5-Day & 09.00 hours & GN(L) & GX(N) & CXL(N) & LN & LN(C) \\
& I6.00 hours & CN,S & CX(L) & profuse LN(C) & LN & L(CN) \\
4-Day & 09.00 hours & LCN & CXN(L) & CXL(N) & LN & - \\
& I6.00 hours & CLN, ${ }^{*}$ S & GX(NL) & LNG & LN & - \\
\hline
\end{tabular}

S, Swollen external genitalia. (), Cell type(s) enclosed may be present. $\mathrm{L}=$ leucocytes, $\mathrm{N}=$ nucleated epithelial cells, $\mathrm{C}=$ cornified epithelial cells, $\mathrm{CX}=$ dense cornified epithelial cells.

* Degenerating eggs from previous ovulation found in smear.

+ The vaginal smears listed here are composites based upon the animals used in the present study and also upon a number of consecutive oestrous cycles observed in mice prior to their use in a different study (Bingel \& Schwartz, 1969).

sometimes found, approximately $3 \frac{1}{2}$ days after the previous ovulation. In the 5-day cycle, therefore, ova were found most frequently on the afternoon of di-oestrus II; in the 4-day cycle, usually on the afternoon of pro-oestrus (Table 4).

As Allen (1922) noted, the appearance of the vaginal orifice and external genitalia varies throughout the cycle. In general, the vaginal orifice tends to be closed throughout di-oestrus and ranges from partly open to widely open during the pro-oestrous to oestrous interval. Swelling of the external genitalia occurs most frequently on the afternoon of pro-oestrus. These observations are especially valuable in the case of irregular mice displaying consecutive cycles of different lengths. Since the vaginal smear content at di-oestrus II (of the 5-day cycle) may be quite similar to the content at pro-oestrus (of the 4-day cycle), noting the appearance of the vaginal orifice and external genitalia can aid in distinguishing between these two stages.

\section{DISCUSSION}

Although the overlapping confidence limits for pituitary LH content found in the present study revealed no significant variation with cycle stage, the mean 
potency appeared highest on the day of di-oestrus I (see Table 3). This observation is in agreement with data reported in the deermouse, Peromyscus maniculatus bairdii (Eleftheriou \& Zolovick, 1967). In the rat, on the other hand, pituitary LH content is maximal on the day of pro-oestrus and minimal on the day of oestrus (Schwartz, 1964). High pituitary LH content was also sometimes found during di-oestrus (Schwartz \& Bartosik, 1962; Schwartz, 1964).

A high degree of variability was observed in the vaginal oestrous cycle of the mouse compared with that of the rat. On the morning of oestrus in the rat, only cornified cells are found in the vaginal smear. By the morning of metoestrus, they have been virtually replaced by leucocytes. The vaginal smear on the day of oestrus in the mouse may contain nucleated epithelial cells as well as cornified cells. Further, the vaginal smear on the morning of metoestrus (that is, the 2nd morning after ovulation) in the mouse is still heavily cornified, although there is usually some leucocytic infiltration. Since vaginal cornification is indicative of oestrogen secretion, these observations suggest the possibility of a slower, more erratic, and more prolonged secretion of oestrogen in the mouse than is found in the rat. Two further possibilities are that the vagina of the mouse may be slower to respond or may be more variable in response than that of the rat.

The present study made it possible to predict the functional stage of the mouse ovary from the appearance of the vaginal smear. Observation of the vaginal smear, twice daily for at least two consecutive cycles, together with observation of the vaginal orifice and external genitalia, permits prediction of the day of pro-oestrus of the next cycle. The establishment of the criteria described made it possible to initiate studies designed to determine the time of LH release and ovulation in the unmated cyclic mouse as reported in the following paper (Bingel \& Schwartz, 1969).

\section{ACKNOWLEDGMENTS}

The authors wish to thank Mr William L. Talley who prepared the tissues for histological examination; Mrs Deatra DeJohnette for her technical assistance in carrying out the LH bio-assays; and the Endocrinology Study Section for the generous supplies of NIH-LH. This study was supported in part by PHS Grants HD-00440 and TO1GM00738.

This work was submitted by one of us (A.S.B.) in partial fulfilment of the requirements for the degree of Doctor of Philosophy in physiology, University of Illinois.

\section{REFERENCES}

AlLEN, E. (1922) The oestrous cycle in the mouse. Am. F. Anat. 30, 297.

Astwoon, E. B. (1939) Changes in the weight and water content of the uterus of the normal adult rat. Am. F. Physiol. 126, 162.

Bingel, A. S. \& Schwartz, N. B. (1969) Timing of LH release and ovulation in the cyclic mouse. 7. Reprod. Fert. 19, 223.

Burss, C. I. (1956) Analysis of the biological assays in U.S.P. XV. Drug Stand. $24,33$.

Burdick, H. O., WhitNey, K. \& EMERson, B. (1942) Observations on the transport of tubal ova. Endocrinology, 31, 100.

Eleftheriou, B. E. \& Zolovick, A. J. (1967) Effects of amygdaloid lesions on plasma and pituitary levels of luteinizing hormone. F. Reprod. Fert. 14, 33. 
Everett, J. W. (1964) Preoptic stimulative lesions and ovulation in the rat: 'thresholds' and LH-release time in late diestrus and proestrus. In: Major Problems in Neuroendocrinology. Eds. E. Bajusz and G. Jasmin. Karger, Basel.

Long, J. A. \& Evans, H. M. (1922) The oestrous cycle in the rat and its associated phenomena. Mem. Univ. Calif. 6, 1.

PARLOW, A. F. (1964) Bioassay of pituitary luteinizing hormone by depletion of ovarian ascorbic acid. In: Human Pituitary Gonadotropins. Ed. A. Albert. Charles C. Thomas, Springfield.

Schwartz, N. B. (1964) Acute effects of ovariectomy on pituitary LH, uterine weight, and vaginal cornification. Am. F. Physiol. 207, 1251.

Schwartz, N. B. \& Bartosix, D. (1962) Changes in pituitary LH content during the rat estrous cycle. Endocrinology, 71, 756.

SNedecor, G. W. (1956) Statistical methods, 5th edn, pp. 87, 90, 268. Iowa State University Press, Ames.

WALLACE, S. J. V. (1965a) Vaginal cytodiagnosis of the estrous cycle of the mouse with fluorescence microscopy. Fert. Steril. 16, 401.

WALLACE, S. J. V. (1965b) A method of predicting the availability of mouse ova during the normal estrous cycle. Fert. Steril. 16, 716.

Whitten, W. K. (1966) Pheromones and mammalian reproduction. Adv. reprod. Physiol. 1, 155. 